\title{
ОСОБЛИВОСТІ ВІДНОВЛЕННЯ ПОРУШЕННЯ ПРОСТОРОВОЇ СТІЙКОСТІ У ВІЙСЬКОВОСЛУЖБОВЦІВ З НАСЛІДКАМИ ЗАКРИТОӤ ЧЕРЕПНО-МОЗКОВОЇ ТРАВМИ ТА АКУБАРОТРАВМИ
}

\author{
А.В. Швець ${ }^{1}$, А.Ю. Кіх ${ }^{2}$, Ю.О. Пархоменко ${ }^{1}$, I.А. Лук'янчук ${ }^{1}$ \\ 1 Украӥнська військово-медична академія, м. Київ \\ ${ }^{2}$ Військово-медичний клінічний лікувально-реабілітаційний центр, м. Ірпінь
}

Вступ. Перебуваючи в умовах бойових дій військовослужбовці піддаються впливу комплексу негативних факторів, які призводять до зниження їх боєготовності та працездатності через наслідки мінно-вибухової травми. Черепно-мозкова травма (ЧМТ) стає складною медико-соціальною проблемою у зв'язку з підвищенням професійної дискваліфікації в багатьох країнах світу. Поєднана патологія практично завжди тягне за собою дефекти у підтриманні контролю за позою, що робить зазначені дослідження актуальними для вчасної діагностики та моніторингу кохлео-вестибулярних порушень $i$ цілеспрямованого відновного лікування наслідків мінно-вибухової травми.

Мета дослідження - дослідити особливості відновлення порушення просторової стійкості у військовослужбовців з наслідками закритої черепно-мозкової травми та акубаротравми в підгострому періоді реабілітації як методу контролю оцінки відновлення їх функціонального стану.

Матеріали та методи. Була обстежена група з 30 військовослужбовців, які мали в анамнезі (більше 3-х місяців) закриту ЧМТ, ускладнену акубаротравмою. Дослідження статичної просторової стійкості (функиії рівноваги) проводили за допомогою приладу «МПФИ стабилограф 1» $i$ пакета програмного забезпечення StabiliS протягом 1 хв. Дослідження проводили при поступленні на реабілітацію та після $14 \pm 2$ діб відновного лікування.

Результати. Показники комп'ютерної стабілометрії, отримані в умовах відсутності зорового контролю за підтриманням вертикальної пози, є найінформативнішими характеристиками, які можуть служити критеріями діагностики порушень функціонального стану після перенесених ЧмТ 3 акубаротравмою. Виявлено, що під час досліджень віддалених наслідків ЧМТ, показники стабілографії суттєво не змінюються під час реабілітації, але варіабельність їх значно зменшується (до реабілітацї була достовірно вищою). Це свідчить про гармонізацію функцій вестибулярного апарату у досліджуваної групи осіб в період підгострої реабілітації.

Висновки. Показано важливість проведення періодичної оцінки функціонального стану за стабілометричними показниками в осіб у процесі лікування акубаротравми, поєднаною зі струсом головного мозку в підгострому періоді реабілітації, для удосконалення та індивідуалізації технологї відновного лікування зазначеної патології. Визначено, що статистично підтверджена позитивна динаміка реабілітації характеризується зменшенням варіабельності характеристик показників стабілометрії серед пацієнтів без зорового контролю: середнє положення центру тиску в фронтальній площині, ексцес коливань центру тиску в фронтальній площині, зсув автокореляційної функції у фронтальній та сагітальній площині до отримання значення коефіцієнта кореляції менше ніж нуль, що свідчить про гармонізацію функцій вестибулярного апарату у досліджуваної групи осіб під впливом лікування та проведених реабілітаційних заходів. Динаміка відновлення більшості показників стабілограми у військовослужбовців за кількісними характеристиками їх відхилення від нормальних значень не залежно від зорового контролю свідчить про наявність позитивних результатів відновного лікування та має певні структурні особливості.

Ключові слова: військовослужбовці, акубаротравма, черепно-мозкова травма, комп'ютерна стабілографія, реабілітація, придатність до військової служби.

Вступ. Основні досягнення в оптимізації медичної допомоги у військових підрозділах і частинах тактичного рівня Збройних Сил (3С) України в сучасних умовах висвітлені в багатьох вітчизняних роботах [1-6]. Разом з тим, в Україні внаслідок бойових дій зросла кількість мінновибухових та інших ушкоджень, які супроводжуються впливом звуків високої інтенсивності та вибухової хвилі. Тому збільшується кількість військовослужбовців зі скаргами на слухові та вестибулярні розлади.

Відомо, що акубаротравма в умовах збройного конфлікту на сході України складала 6,6 \% - 7,1 \% в загальній структурі бойових санітарних втрат [12]. В зв'язку з цим виникає необхідність ранньої діагностики та цілеспрямованого лікування пацієнтів 3 кохлеовестибулярною патологією, викликаною акубаротравмою. Водночас ступень складності посттравматичного (реабілітаційного) періоду досить часто визначається як своєчасністю 
встановлення діагнозу «акубаротравма», так і визначеністю коморбідної патології, пов'язаної із множинними та поєднаними ЧМТ.

В сучасних дослідженнях також опрацьовується один 3 ключових аспектів акубаротравми, яка визначається тим, що ті самі фактори призводять до уражень не тільки органів слуху, а й до ураження інших відділів ЦНС [13]. В цій роботі показано, що акубаротравму слід розглядати як проблему, яка виходить за рамки ураження системи органу слуху, а скоріш за все як множинну травму, що вкладається в поняття мінно-вибухової травми або вибухової травми та потребує комплексного підходу до діагностики наслідків впливу вибуховоі хвилі, що формує нові виклики та загрози щодо збереження здоров'я військовослужбовців в умовах специфіки ведення бойових дій в зоні ООС.

Мета дослідження - дослідити особливості відновлення порушення просторової стійкості у військовослужбовців 3 наслідками закритої черепно-мозкової травми та акубаротравми в підгострому періоді реабілітації як методу контролю оцінки відновлення їх функціонального стану.

Матеріали та методи. Було обстежено групу з 30 чоловіків військовослужбовців, які мали в анамнезі (більше 3-х місяців) закриту ЧМТ, ускладнену акубаротравмою.

3 метою коректного набору клінічного матеріалу та однорідності отриманих даних у дослідження включені пацієнти з достовірним діагнозом (втрата свідомості після травми голови протягом 20-30 хв). У всіх пацієнтів під час отоневрологічного огляду виявлено нейросенсорну приглухуватість помірного ступеня. Критерієм виключення з дослідження були супутня соматична патологія, яка погіршує функцію вертикального положення тіла (наявність судинного, нейродегенеративного, дисметаболічного або іншого органічного ураження головного мозку). У відповідності з перерахованими критеріями в дослідження включено пацієнтів з ЧМТ та нейросенсорною приглухуватістю, середній вік яких склав $(35,4 \pm 11,7)$ років, середня довжина тіла - $(178,8 \pm 8,1)$ см, середня маса тіла - $(76,5 \pm 11,9)$ кг.

Дослідження проводили на базі Військово-медичного клінічного лікувальнореабілітаційного центру при поступленні на реабілітацію та після $14 \pm 2$ діб відновного лікування.

Дослідження статичної просторової стійкості (функції рівноваги) проводили за допомогою приладу «МПФИ стабилограф 1» і пакета програмного забезпечення StabiliS протягом 1 хв. Комплекс дозволяє здійснювати запис коливань тіла людини, що знаходиться в положенні стоячи. Дослідження психофізіологічних характеристик за допомогою приладу побудовані на принципі реєстрації коливань проекції центру тиску людини на площину опори [8]. Дослідження здійснювали в такий спосіб: випробуваний перебуває у вертикальному положенні на тензометричній платформі. Потім відбувалася реєстрація коливань центру тиску протягом 1 хв 3 відкритими та 1 хв із закритими очима, після чого здійснювався аналіз отриманих записів за показниками: Length, мм - довжина траєкторії коливань центру тиску; AvgSpeed, мм /с - середня швидкість переміщення центру тиску; Angle, гр - усереднений кут коливань центру тиску; Pup2Sigma,\% - відносна кількість точок стабілограми, що лежать у межах подвоєного стандартного відхилення; PirsonXY - коефіцієнт лінійної кореляції між коливаннями в фронтальній і сагітальній площинах; RangeX, мм - розмах коливань центру тиску в фронтальній площині; RangeY, мм - розмах коливань центру тиску в сагітальній площині; LengthX, мм - довжина траєкторії коливань центру тиску в фронтальній площині; LengthY, мм - довжина траєкторії коливань центру тиску в сагітальній площині; MeanX, мм середнє положення центру тиску в фронтальній площині; MeanY, мм - середнє положення центру тиску в сагітальній площині; StdDevX, мм - стандартне відхилення коливань центру тиску в фронтальній площині; StdDevY, мм - стандартне відхилення коливань центру тиску в сагітальній площині; SkewX, мм - асиметрія коливань центру тиску в фронтальній площині; SkewY, мм - асиметрія коливань центру тиску в сагітальній площині; KurtosisX, мм - ексцес коливань центру тиску в фронтальній площині; KurtosisY, мм - ексцес коливань центру тиску в сагітальній площині; wAvgFX, Гц - середньозважена частота спектра коливань центру тиску в фронтальній площині; wAvgFY, Гц - середньозважена частота спектра коливань центру тиску в сагітальній площині; wAvgFXY, Гц - середньозважена частота кросспектра коливань центру 
тиску в фронтальній і сагітальній площині; ССОХ, с - зсув автокореляційної функції у фронтальній площині до отримання значення коефіцієнта кореляції менше ніж нуль; ССОY, с зсув автокореляційної функції в сагітальній площині до отримання значення коефіцієнта кореляції менше ніж нуль; KFR, \% - якість функції рівноваги; КРВ, у.о. - коефіцієнт передбачення імовірності майбутнього коливального руху у порівнянні з попереднім, розрахований на основі аналізу автокореляційної функції. KFR розраховується за допомогою аналізу векторів зсуву центру тиску щодо осей координат. Вибір даного параметра не випадковий, так як він $\epsilon$ найстабільнішим інтегральним показником стійкості тіла $[9,11]$.

Вибір зазначених характеристик не випадковий, оскільки він грунтується на обранні тих параметрів, які піддаються нейрофізіологічному трактуванню та визначенню фізичного зв'язку (залежності) реєстрованих значень від технічної характеристики та особливостей пристрою, що реєструє показники [8].

Вважають, що в нормі частота коливання тіла становить близько 4 Гц [10]. Статистичну обробку одержаних результатів проводили в програмному пакеті STATISTICA 6.0 методами дескриптивної статистики.

Результати дослідження та їх обговорення. При порівнянні значень показників стабілометрії у пацієнтів із розплющеними очима до та після реабілітації дані були розподілені таким чином: довжина траєкторії коливань центру тиску до реабілітації складала $601,11 \pm 162,78$ мм, після реабілітації - 626,86 $\pm 216,25$ мм, середня швидкість переміщення

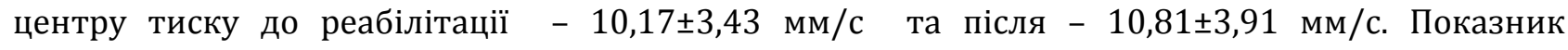
усередненого кута коливань центру тиску до реабілітації складав $15,58^{\circ} \pm 9,19$, після $11,61^{\circ} \pm 10,33$ (табл. 1 ).

Таблиця 1.

Різниця показників стабілометрії у досліджуваній групі до та після реабілітації із зоровим контролем

\begin{tabular}{|l|l|l|l|l|l|l|l|}
\hline Показники & Меап & \multicolumn{2}{l|}{ Std.Dev } & p & F-ratio & Р (F) \\
\cline { 2 - 7 } & До р-ції & Після р-ції & До р-ції & $\begin{array}{l}\text { Після р- } \\
\text { ції }\end{array}$ & & & \\
\hline Length, мм & 601,11 & 626,86 & 162,78 & 216,25 & $>0,05$ & 1,765 & $>0,05$ \\
\hline AvgSpeed, мм/c & 10,17 & 10,81 & 3,43 & 3,91 & $>0,05$ & 1,3 & $>0,05$ \\
\hline Angle, гр & 15,58 & 11,61 & 9,19 & 10,33 & $>0,05$ & 1,26 & $>0,05$ \\
\hline Pup2Sigma, \%" & 93,79 & 93,62 & 1,97 & 1,71 & $>0,05$ & 1,33 & $>0,05$ \\
\hline PirsonXY & 0,23 & 0,17 & 0,13 & 0,13 & $>0,05$ & 1,036 & $>0,05$ \\
\hline RangeX, мм & 18,52 & 20,24 & 7,99 & 11,55 & $>0,05$ & 2,09 & $>0,05$ \\
\hline RangeY, мм & 21,48 & 23,42 & 9,11 & 14,92 & $>0,05$ & 2,68 & $<0,05$ \\
\hline LengthX, мм & 347,15 & 360,3 & 102.96 & 139,7 & $>0,05$ & 1,841 & $>0,05$ \\
\hline LengthY, мм & 415,08 & 433,4 & 119,44 & 147,7 & $>0,05$ & 1,53 & $>0,05$ \\
\hline MeanX, мм & 9,39 & 6,44 & 10,31 & 8,19 & $>0,05$ & 1,583 & $>0,05$ \\
\hline MeanY, мм & 11,89 & 14,08 & 14,12 & 15,66 & $>0,05$ & 1,23 & $>0,05$ \\
\hline StdDevX, мм & 3,97 & 4,36 & 1,91 & 2,62 & $>0,05$ & 1,89 & $>0,05$ \\
\hline StdDevY, мм & 4,68 & 5,22 & 2,07 & 3,71 & $>0,05$ & 3,19 & $<0,05$ \\
\hline SkewX & 0,13 & 0,13 & 0,1 & 0,1 & $>0,05$ & 1,079 & $>0,05$ \\
\hline SkewY & 0,14 & 0,2 & 0,1 & 0,22 & $>0,05$ & 4,59 & $<0,05$ \\
\hline KurtosisX & 2,5 & 2,47 & 0,3 & 0,28 & $>0,05$ & 1,164 & $>0,05$ \\
\hline KurtosisY & 2,45 & 2,59 & 0,25 & 0,42 & $>0,05$ & 2,7 & $<0,05$ \\
\hline CC0X, с & 8,87 & 9,83 & 6,95 & 6,77 & $>0,05$ & 1,05 & $>0,05$ \\
\hline CCOY, с & 9,31 & 6,89 & 6,35 & 4,72 & $>0,05$ & 1,81 & $>0,05$ \\
\hline wAvgFX, Гц & 0,32 & 0,33 & 0,08 & 0,08 & $>0,05$ & 1,08 & $>0,05$ \\
\hline wAvgFY, Гц & 0,31 & 0,32 & 0,07 & 0,07 & $>0,05$ & 1,065 & $>0,05$ \\
\hline KPB, y.o. & 0,94 & 0,96 & 0,15 & 0,05 & $>0,05$ & 7,46 & $<0,05$ \\
\hline KFR, \% & 66,25 & 62,39 & 14,32 & 16,33 & $>0,05$ & 1,3 & $>0,05$ \\
\hline & & & & & & & \\
\hline
\end{tabular}

у даному порівнянні достовірна різниця між показниками не відмічена в жодному 3 випадків. Однак визначаються показники із достовірною зміною їх середніх квадратичних відхилень, а саме: ексцес коливань центру тиску в сагітальній площині, асиметрія коливань 
центру тиску в сагітальній площині, стандартне відхилення коливань центру тиску в сагітальній площині, розмах коливань центру тиску в сагітальній площині, коефіцієнт передбачення майбутнього коливального руху - КРВ.

На наступному етапі порівнювались значення показників стабілометрії у пацієнтів із заплющеними очима до та після реабілітації. Результати такого аналізу наведено у таблиці 2.

У даному порівнянні статистично достовірною $(\mathrm{p}<0,05) \in$ різниця між показниками CCOY та MeanX, в решті випадків також суттєвих змін не виявлено. За критерієм Фішера та оцінкою його достовірності, було визначено, що статистично підтверджена достовірність різниці цих характеристик спостерігається за показниками: середнє положення центру тиску в фронтальній площині, ексцес коливань центру тиску в фронтальній площині, зсув автокореляційної функції у фронтальній та сагітальній площині до отримання значення коефіцієнта кореляції менше ніж нуль, а також показник КРВ.

Динаміка середніх квадратичних відхилень показників стабілометрії серед пацієнтів без зорового контролю відображена на рис. 1.

Таблиця 2.

Різниця показників стабілометрії у досліджуваній групі до та після реабілітації без зорового контролю

\begin{tabular}{|c|c|c|c|c|c|c|c|}
\hline \multirow[t]{2}{*}{ Показники } & \multicolumn{2}{|l|}{ Mean } & \multicolumn{2}{|l|}{ Std.Dev } & \multirow[t]{2}{*}{$\mathrm{p}$} & \multirow[t]{2}{*}{ F-ratio } & \multirow[t]{2}{*}{$\mathrm{P}(\mathrm{F})$} \\
\hline & До р-ції & $\begin{array}{l}\text { Після р- } \\
\text { ції }\end{array}$ & До р-ції & $\begin{array}{l}\text { Після р- } \\
\text { ції }\end{array}$ & & & \\
\hline Length, MM & 1023,27 & 1055,96 & 378,71 & 371,29 & $>0,05$ & 1,04 & $>0,05$ \\
\hline AvgSpeed, мм/c & 18,04 & 18,61 & 7,31 & 7,09 & $>0,05$ & 1,062 & $>0,05$ \\
\hline Angle, гр & 14,59 & 14,89 & 9,02 & 10,65 & $>0,05$ & 1,39 & $>0,05$ \\
\hline Pup2Sigma, \%" & 92,66 & 92,18 & 1,46 & 1,87 & $>0,05$ & 1,64 & $>0,05$ \\
\hline PirsonXY & 0,18 & 0,19 & 0,11 & 0,14 & $>0,05$ & 1,46 & $>0,05$ \\
\hline RangeX, MM & 23,55 & 23,35 & 9,63 & 11,09 & $>0,05$ & 1,32 & $>0,05$ \\
\hline LengthX, MM & 537,97 & 605,15 & 222,76 & 252,34 & $>0,05$ & 1,28 & $>0,05$ \\
\hline LengthY, MM & 753,33 & 732,27 & 273,88 & 247,63 & $>0,05$ & 1,22 & $>0,05$ \\
\hline MeanX, мм & 11,18 & 5,83 & 11,11 & 6,37 & $<0,05$ & 2,44 & $<0,05$ \\
\hline MeanY, мм & 11,72 & 15,13 & 10,64 & 15,8 & $>0,05$ & 2,2 & $>0,05$ \\
\hline StdDevX, мм & 4,84 & 4,96 & 1,95 & 2,3 & $>0,05$ & 1,4 & $>0,05$ \\
\hline StdDevY, MM & 6,6 & 7,18 & 2,55 & 3,77 & $>0,05$ & 2,19 & $>0,05$ \\
\hline SkewX & 0,16 & 0,15 & 0,11 & 0,12 & $>0,05$ & 1,13 & $>0,05$ \\
\hline SkewY & 0,14 & 0,14 & 0,12 & 0,12 & $>0,05$ & 1,04 & $>0,05$ \\
\hline KurtosisX & 2,55 & 2,45 & 0,35 & 0,13 & $>0,05$ & 7,63 & $<0,05$ \\
\hline KurtosisY & 2,4 & 2,58 & 0,3 & 0,34 & $>0,05$ & 1,27 & $>0,05$ \\
\hline $\mathrm{CCOX}, \mathrm{c}$ & 7,08 & 4,4 & 6,59 & 3,47 & $>0,05$ & 3,61 & $<0,05$ \\
\hline $\mathrm{CCOY}, \mathrm{c}$ & 5,48 & 9,92 & 4,84 & 8,4 & $<0,05$ & 3,01 & $<0,05$ \\
\hline KPB & 0,93 & 0,95 & 0,11 & 0,05 & $>0,05$ & 4,24 & $<0,05$ \\
\hline DegKPB & 5,05 & 3,58 & 4,57 & 2,54 & $>0,05$ & 3,23 & $<0,05$ \\
\hline KFR, \% & 42,25 & 39,02 & 18,79 & 17,25 & $>0,05$ & 1,19 & $>0,05$ \\
\hline
\end{tabular}

Таким чином, під час досліджень віддалених наслідків чМТ нами було виявлено, що показники даних стабілографії загалом суттєво не змінюються під час реабілітації, однак варіабельність більшості показників зменшилась, що свідчить про гармонізацію функцій вестибулярного апарату у досліджуваної групи осіб під впливом лікування та проведених реабілітаційних заходів.

У ході дослідження для більш детального вивчення особливостей впливу реабілітації на віддалені наслідки ЧМТ у пацієнтів, було проаналізовано частки пацієнтів з відхиленнями від норми [7] за кожним показником стабілограми у всій обстежуваній групі, як з відкритими очима, так і з закритими. Порівнювались дані, отримані до проходження пацієнтами реабілітації та після неї. Одержані відносні показники наведені на рис. 2 


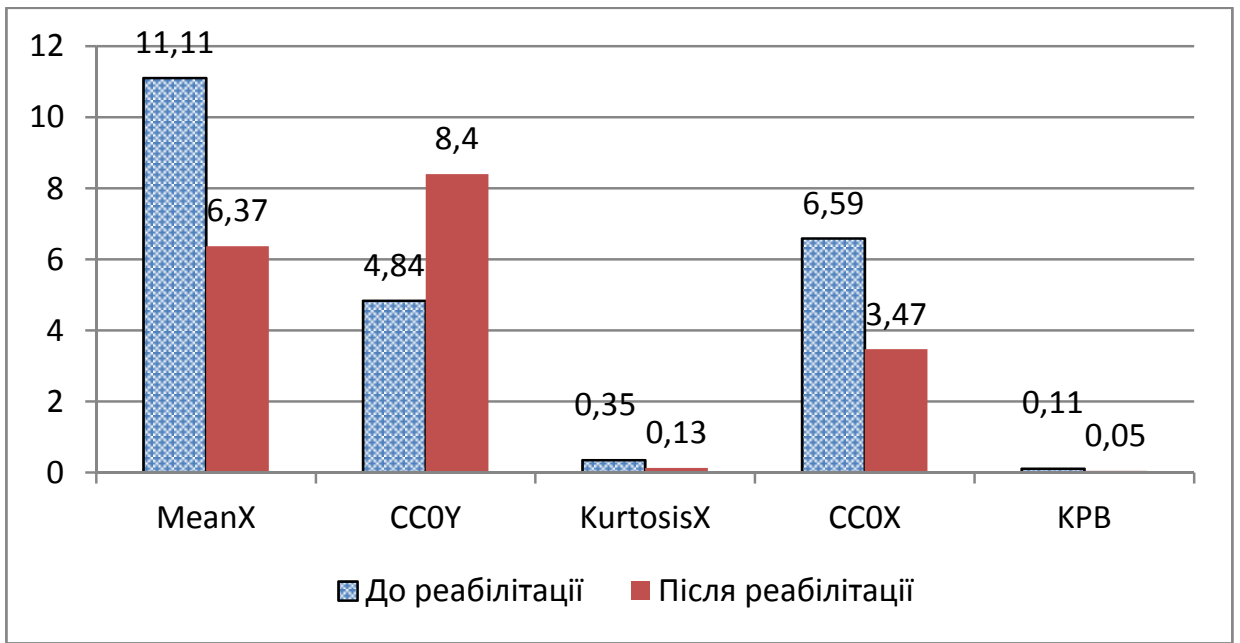

Рисунок 1. Динаміка достовірних змін середніх квадратичних відхилень показників стабілометрії серед пацієнтів без зорового контролю.
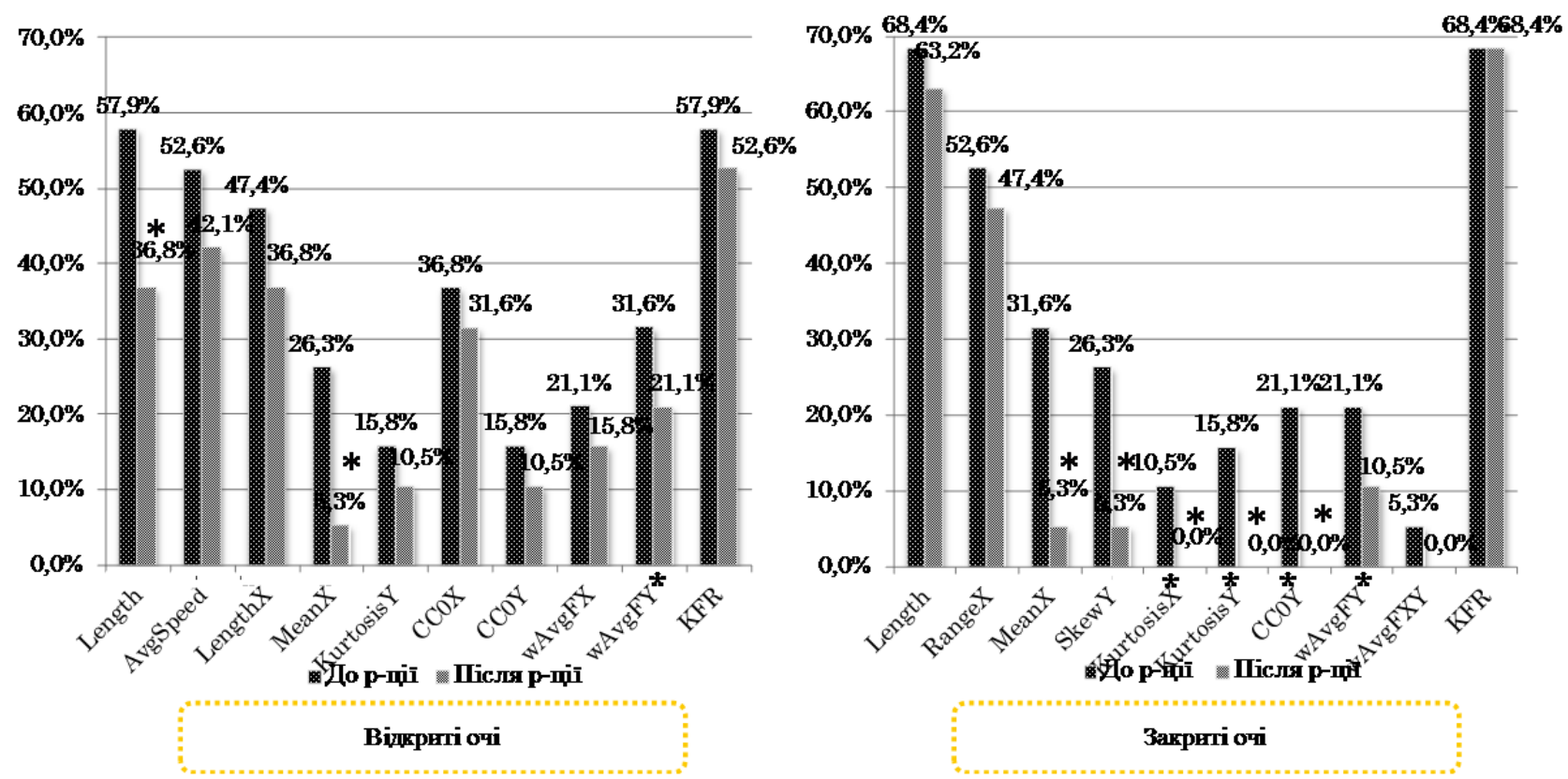

*- Достовірність різниці показників до та після реабілітації р<0,05

Рисунок 2. Динаміка відновлення показників стабілограми у військовослужбовців за кількісними ознаками характеристики відхилення від нормальних значень

3 наведених даних видно, що не у всіх пацієнтів показники стабілограми прийшли до норми після реабілітації. Слід відмітити, що за деякими показниками відсоток пацієнтів, чиї дані виходять за межі норми, збільшується після реабілітації, або залишається незмінним. Однак, це лише пілотне дослідження, що базується на незначному розмірі вибірки, використаної для аналізу.

Отже, порівнявши показники стабілограми пацієнтів із зоровим контролем, було визначено, що частка пацієнтів з відхиленнями за показниками: Length (довжина траєкторії коливань центру тиску), та MeanX (середнє положення центру тиску в фронтальній площині) достовірно зменшилась після реабілітації $(\mathrm{p}<0,05)$. За іншими показниками відмічена тенденція до покращення стабілографічних характеритсик.

Порівнявши показники стабілограми пацієнтів без зорового контролю, було визначено, що частка пацієнтів з відхиленнями за показниками MeanX (середнє положення центру тиску в фронтальній площині), SkewY (асиметрія коливань центру тиску в сагітальній площині), 
KurtosisX (ексцес коливань центру тиску в фронтальній площині), KurtosisY (ексцес коливань центру тиску в сагітальній площині), ССОY (зсув автокореляційної функції в сагітальній площині до отримання значення коефіцієнта кореляції менше ніж нуль), достовірно зменшується $(\mathrm{p}<0,05)$, за іншими показниками залишається без достовірних змін з тенденцією до покращення.

Показники комп'ютерної стабілометрії, отримані в умовах відсутності зорового контролю за підтриманням ВП, $€$ найінформативнішими характеристиками, які можуть служити критеріями діагностики порушень функціонального стану після перенесених ЧМТ 3 акубаротравмою в гострому періоді. В попередньому дослідженні [7] були виділені шість найінформативніших показники стабілометрії (загальна довжина траєкторії коливань центру тиску та їі характеристики у сагітальній площині; середня швидкість переміщення центру тиску; якість функції рівноваги, та середньозважена частота спектру коливань центру тиску у фронтальній площині) серед 23 досліджуваних, за якими можна оцінити ступінь покращання функціонального стану під час гострої реабілітації в умовах стаціонару. 3 часом, і це цілком зрозуміло, що кількість таких показників зменшиться. В нашому випадку їх залишилось лише два MeanX (середнє положення центру тиску в фронтальній площині) та CCOY (зсув автокореляційної функції в сагітальній площині до отримання значення коефіцієнта кореляції менше ніж нуль), що покращилися після реабілітації у віддаленому періоді ЧМТ. При цьому за окремими показниками достовірно зменшилась частка пацієнтів, у яких спостерігалось відхилення показників від норми, особливо в умовах відустності зорового контролю.

Таким чином, у цьому дослідженні (підгострий період реабілітації) показано, що показники даних стабілографії у своїй більшості суттєво не змінюються під час реабілітації, однак показники варіабельності більшості характеристик зменшились, також достовірно покращились (зменшились) величини середніх квадратичних відхилень показників стабілометрії серед пацієнтів без зорового контролю, що свідчить про гармонізацію функцій вестибулярного апарату у досліджуваної групи осіб під впливом лікування та проведених реабілітаційних заходів.

\section{Висновки}

1. Показано важливість проведення періодичної оцінки функціонального стану за стабілометричними показниками у осіб в процесі лікування акубаротравми, поєднаною 3 легким струсом головного мозку в підгострому періоді реабілітації, для удосконалення та індивідуалізації технології відновного лікування зазначеної патології.

2. Визначено, що позитивна динаміка реабілітації в підгострому періоді характеризується зниженням варіації окремих показників стабілографії: середнє положення центру тиску в фронтальній площині, ексцес коливань центру тиску в фронтальній площині, зсув автокореляційної функції у фронтальній та сагітальній площині під час обстеження пацієнтів без зорового контролю, що свідчить про гармонізацію функцій вестибулярного апарату у досліджуваної групи осіб під впливом лікування та проведених реабілітаційних заходів.

3. Динаміка відновлення більшості показників стабілограми у військовослужбовців за кількісними характеристиками їх відхилення від нормальних значень не залежно від зорового контролю свідчить про наявність позитивних результатів відновного лікування у підгострому реабілітаційному періоді та має певні структурні особливості, що полягають у достовірному зменшенні частки пацієнтів, у яких спостерігалось відхилення від норми таких показників як: середнє положення центру тиску в фронтальній площині, зсув автокореляційної функції в сагітальній площині, ексцес коливань центру тиску в фронтальній площині, ексцес коливань центру тиску в сагітальній площині, асиметрія коливань центру тиску в сагітальній площині.

\section{Література}

1. Бадюк M.І., Середа І.К., Микита О.О., Ковида Д.В., Жупан Б.Б. Оптимізація медичної допомоги і військових підрозділах і частинах тактичного рівня Збройних Сил України у сучасних умовах. Здоров'я нащіï. 2016. №4/1(41). С. 13-18. 
2. Білий В.Я. Верба А.В., Жаховський В.О. Еволюція поглядів та розвиток системи лікувальноевакуаційного забезпечення військ - уроки для Збройних Сил України. Медичне забезпечення антитерористичної операції: науково-організаційні та медико-соціальні аспекти : збірник наукових праць. - К. : Пріоритети, 2016. - С. 60-76.

3. Гур'єв С.О., Танасієнко П.В., Гуселетова Н.В., Мостипан 0.О. Аналіз медико-санітарних наслідків військових дій під час проведення сучасних контртерористичних операцій . Екстрена медицина від науки до практики. 2014. №4. С. 3-8

4. Chandrasekhar S. S. The assessment of balance and dizziness in the TBI patient. NeuroRehabilitation. 2013. V. 32, №3. P.445-454.

5. Майданюк В.П. Аналіз ефективності функціонування мобільних лікарсько-сестринських бригад ВМКЦ Південного регіону в АТО . Матеріали науково-практичної конференцї «Проблемні питання надання хірургічної допомоги пораненим в АТО» (м. Київ, квітень 2015 р.). К. : ГВКГ, 2015. С. 10.

6. Ritenour A.E., Blackbourne L.H., Kelly J.F., et al. Incidence of primary blast injury in US military overseas contingency operations: a retrospective study. Ann Surg. 2010. №251. С. 1140-1144.

7. Кальниш В. В., Швець А. В., Горолюк Д. О. Клініко функціональні особливості відновлення здоров'я у осіб з наслідками черепномозкової травми після перебування в зоні бойових дій за показниками стабілографічного дослідження. Український журнал з проблем медицини праці. 2018 . № 3. C. 22-33.

8. Кочина М. Л., Камінський А. О. Апаратнопрограмний комплекс для дослідження статодинамічної стійкості людини. Прикладна радіоелектроніка. 2012. Т. 11, № 1. С. 120-124.

9. Слива С. С. Биологическая обратная связь на основе методов и средств компьютерной стабилографии. Биоуправление-4: Теория и практика. Новосибирск, 2002. С. 294-299.

10. Гурфинкель В. С., Коц Я. М., Шик М. Л. Регуляция позы человека. Москва : Наука, 1965. 256 с.

11.Усачев В. И., Доценко В. И., Кононов А. Ф., Артемов В. Г. Новая методология стабилометрической диагностики нарушения функции равновесия тела. Вестник оториноларингологии. 2009. № 3. С. 19-22.

12. Галушка А.М., Подолян Ю.В., Швець А.В., Іванцова Г.В., Ричка О.В. Ретроспективний аналіз поширеності симптомів характерних для акубаротравми у поранених та хворих військовослужбовцівучасників АТО (ООС). Військова медищина України. 2019. Т. 19, № 2. С. 17-24.

13. Галушка А.М., Подолян Ю.В., Швець А.В., Горшков О.О. Особливості бойового травмування, що супроводжувалося акубаротравмою у військовослужбовців-учасників бойових дій. Військова медицина України. 2019. Т. 19, № 3. С. 56-66.

\section{References}

1. Badiuk M. I., Sereda I. K., Mykyta O. O., Kovyda D. V., \& Zhupan B. B. (2016). Optymizatsiia medychnoi dopomohy i viiskovykh pidrozdilakh i chastynakh taktychnoho rivnia Zbroinykh Syl Ukrainy u suchasnykh umovakh [Optimization of medical care in military units and tactical level units of theArmed Forces of Ukraine in modern conditions]. Ukraina. Zdorovia natsii, 4/1(41), 13-18. [in Ukrainian].

2. Bilyi V. Ya., Verba A. V., \& Zhakhovskyi V. O. (2016). Evoliutsiia pohliadiv ta rozvytok systemy likuvalno-evakuatsiinoho zabezpechennia viisk - uroky dlia Zbroinykh Syl Ukrainy [Evolution of views and development of the system of medical and evacuation support for troops - lessons for the Armed Forces of Ukraine]. Medychne zabezpechennia antyterorystychnoi operatsii: naukovo-orhanizatsiini ta medyko-sotsialni aspekty. Kyiv: Priorytety, 60-76. [in Ukrainian].

3. Guriev S., Tanasienko P., Guseletova N., \& Mostipan, O. (2014). Analiz medyko-sanitarnykh naslidkiv viiskovykh dii pid chas provedennia suchasnykh kontrterorystychnykh operatsii [Analysis of the health consequences of military action during the current counter-terrorism operations]. Ekstrena medytsyna vid nauky do praktyky, 4, 3-8. [in Ukrainian].

4. Chandrasekhar S. S. The assessment of balance and dizziness in the TBI patient (2013). NeuroRehabilitation. 32 (3). 445-454.

5. Maydanyuk V.P. (2015). Analiz efektyvnosti funktsionuvannia mobilnykh likarsko-sestrynskykh bryhad VMKTS Pivdennoho rehionu v ATO [Analysis of the effectiveness of the functioning of the mobile medical nursing brigades of the Southern AUCC of the Southern Region in the ATO]. Problemni pytannia nadannia khirurhichnoi dopomohy poranenym v ATO. Proceedings of the Scientific and Practical Conference. Kyiv: GVKG, 10. [in Ukrainian].

6. Ritenour A.E., Blackbourne L.H., Kelly J.F., et al. (2010). Incidence of primary blast injury in US military overseas contingency operations: a retrospective study. Ann Surg. 251.1140-1144.

7. Kalnysh V. V., Shvets A. V., Gorolyuk D. O. (2018). Clinical and functional features of health recovery in persons with consequences of traumatic brain injuries after staying in the combat zone by indices of a stabilographic study. Ukrainian Journal of Occupational Health, (3), 22-33. doi: 10.33573/ujoh2018.03.022 
8. Kochina M. L. and Kaminsky A. O. (2012). «A hardware and software complex for studying human posturegraphy», Prikladnaya radioelektronika, 11 (1), 120-124. [in Ukrainian]

9. Sliva S. S. (2002). «Biological feedback on the basis of methods and means of computer stabilography», Bioupravleniye-4: Teoriya i praktika, Novosibirsk, 294-299.

10. Gurfinkel V. S., Kots Ya. M. and Chic M. L. (1965). Regulyatsiya pozy cheloveka [Regulation of the human posture]. Moscow : Nauka, 256 p.

11. Usachev V. I., Dotsenko V. I., Kononov A. F. and Artemov V.G. (2009), "A new methodology for stabilometric diagnostics of disorders of the body equilibrium function», Bulleten otorinolaringologii, 3, 19-22.

12. Halushka A. M., Podolyan Y.V., Shvets A.V., Ivantsova G.V., Rychka O.V. (2019) Retrospective analysis of the prevalence of symptoms characteristic of acubarotrauma in wounded and sick servicemen participating in the ATO (JFO). Military medicine of Ukraine. 19 (2). 17-24. [in Ukrainian].

13. Halushka A.M., Podolyan Y.V., Shvets A.V., Gorshkov O.0. (2019) Features of combat injuries accompanied by acubarotrauma in servicemen participating in hostilities. Military medicine of Ukraine. 19 (3). 56-66. [in Ukrainian].

\title{
ОСОБЕННОСТИ ВОССТАНОВЛЕНИЯ НАРУШЕНИЯ ПРОСТРАНСТВЕННОЙ УСТОЙЧИВОСТИ У ВОЕННОСЛУЖАЩИХ С ПОСЛЕДСТВИЯМИ ЗАКРЫТОЙ ЧЕРЕПНО-МОЗГОВОЙ ТРАВМЫ И АКУБАРОТРАВМЫ
}

\section{А. В. Швец, ${ }^{1}$ А. Ю. Ких, ${ }^{2}$ Ю. А. Пархоменко, ${ }^{1}$ И. А. Лукянчук ${ }^{1}$}

\author{
1Украинская военно-медицинская академия, г. Киев \\ ${ }^{2}$ Военно-медицинский клинический лечебно-реабилитационный центр, г. Ирпень
}

Введение. Находясь в условиях боевых действий военнослужащие подвергаются воздействию комплекса негативных факторов, которые приводят к снижению их боеготовности и работоспособности из-за последствий минно-взрывной травмы. Черепно-мозговая травма (ЧМТ) становится сложной медико-социальной проблемой в связи с повышением профессиональной дисквалификации во многих странах мира. Сочетанная патология практически всегда влечет за собой дефекты в поддержании контроля за позой, что делает указанные исследования актуальными для своевременной диагностики и мониторинга кохлео-вестибулярных нарушений и целенаправленного восстановительного лечения последствий минно-взрывной травмы.

Цель - исследовать особенности восстановления нарушения пространственной устойчивости у военнослужащих с последствиями закрытой черепно-мозговой травмы и акубаротравмы в подостром периоде реабилитации как метода контроля оценки восстановления их функционального состояния.

Материалы и методы. Была обследована группа из 30 военнослужащих которые имели в анамнезе (более 3-х месяцев) закрытую ЧМТ, осложненную акубаротравмой. Исследование статической пространственной устойчивости (функции равновесия) проводили с помощью прибора «МПФИ стабилограф 1» и пакета программного обеспечения StabiliS в течение 1 мин. У лиц группы исследования проводили при поступлении на реабилитацию и после $14 \pm 2$ суток восстановительного лечения.

Результаты. Показатели компьютерной стабилометрии, полученные в условиях отсутствия зрительного контроля за поддержанием вертикальной позы, являются наиболее информативными характеристиками, которые могут служить критериями диагностики нарушений функционального состояния после перенесенных ЧМТ с акубаротравмой. Обнаружено, что во время исследований отдаленных последствий ЧМТ, показатели стабилографии существенно не изменяются во время реабилитации, но вариабельность их значительно уменьшается (до реабилитации была достоверно выше). Это свидетельствует о гармонизации функций вестибулярного аппарата у исследуемой группы лиц в период подострой реабилитации.

Выводы. Показана целесообразность проведения периодической оценки функционального состояния по стабилометрическим показателям у лиц в процессе лечения акубаротравмы, сочетанной с сотрясением головного мозга в подостром периоде реабилитации, для совершенствования и индивидуализации технологии восстановительного лечения данной патологии. Положительная динамика реабилитации характеризуется уменьшением вариабельности ряда характеристик стабилографии среди пациентов без зрительного контроля: д, свидетельствует о гармонизации функций вестибулярного аппарата в исследуемой группе лиц под влиянием лечения и проведенных реабилитационных мероприятий. Динамика восстановления большинства показателей стабилограммы у военнослужащих по количественным характеристиками их отклонения от нормальных значений независимо от зрительного контроля свидетельствует о наличии положительных результатов восстановительного лечения и имеет определенные структурные особенности. 
Ключевые слова: военнослужащие, акубаротравма, черепно-мозговая травма, компьютерная стабилометрия, реабилитация, годность к военной службе.

\title{
FEATURES OF RESTORATION OF SPATIAL STABILITY DISORDERS AMONG SERVICEMEN WITH TRAUMATIC BRAIN INJURY AND ACUBAROTRAUMA CONSEQUENCES
}

\author{
A. V. Shvets' ${ }^{1}$, A.Y. Kikh², Y.O. Parkhomenko', I. A. Lukyanchuk ${ }^{1}$ \\ ${ }^{1}$ Ukrainian Military Medical Academy, Kyiv \\ ${ }^{2}$ Military Medical Clinical Treatment \& Rehabilitation Center, Irpin
}

Introduction. Being in the conditions of military operations, military personnel are exposed by a complex of negative factors, which lead to decrease their combat readiness and working capacity due to the consequences of mine explosive injury. Traumatic brain injury (TBI) is becoming a complex medical and social problem due to increased professional disqualification in many countries of the world. Combined pathology always entails defects in maintaining postural control, which makes these studies relevant for the timely diagnosis and monitoring of cochleo-vestibular disorders and targeted rehabilitation treatment of the acubarotrauma effects.

The purpose of research was to investigate the features of restoring spatial stability disorders in military personnel with the consequences of closed TBI and acubarotrauma at the subacute rehabilitation period as assessing method for monitoring of their functional state restoration.

Materials and methods. A group of 30 servicemen who had in history (more than 3 months) Milde TBI complicated by acubarotrauma has been examined. The study of static spatial stability (balance function) was carried out using the "Stabilograph-1 Complex" and the "StabiliS" software package for 1 min. In individuals of the group, studies were carried out upon admission to rehabilitation and after $14 \pm 2$ days of rehabilitation treatment.

Results. The indicators of computer posturography obtained in the absence of visual control over the maintenance of the vertical pose are the most informative characteristics that can serve as criteria for diagnosing functional disorders after a mTBI with acubarotrauma. It was found that during studies of the long-term consequences of $\mathrm{mTBI}$, stabilization indices do not change significantly during rehabilitation, but their variability decreases significantly (before rehabilitation it was significantly higher). This indicates harmonization of vestibular apparatus functions in the studied group during subacute rehabilitation.

Conclusions. The importance of a periodic assessment of the functional state according to posturography indicators in individuals during the treatment of acubarotrauma combined with mTBI in the subacute period of rehabilitation is shown to improve and individualize the technology of rehabilitation treatment of this pathology. It was found that statistically confirmed positive dynamics of rehabilitation is characterized by a decrease in the variability of the characteristics of such parameters among patients without visual control as: the average position of the pressure center in the frontal plane, the excess oscillations of the pressure center in the frontal plane, the shift of the autocorrelation function in the frontal and sagittal planes to obtain a correlation coefficient value less than zero, indicates a harmonization of functions vestibular apparatus in the studied group under the influence of rehabilitation measures. The dynamics of the restoration of the majority of posturography indicators in military personnel by the quantitative characteristics of their deviation from normal values, regardless of visual control, indicates the presence of positive results of rehabilitation and has certain structural features.

Key words: military personnel, acubarotrauma, traumatic brain injury, computer posturography, rehabilitation, suitability for military service.

Конфлікт інтересів: відсутній.

Conflicts of interest: authors have no conflict of interest to declare.

$A$ - концепція та дизайн дослідження; $B$ - збір даних; $C$ - аналіз та інтерпретація даних; $D$ написання статmі; $E$ - редагування статmі; F- остаточне затвердження статті

\section{Відомості про авторів:}

Швець А. В., А, в, С ,D, E, F полковник медичної служби, д-р мед. наук, старший науковий співробітник, заступник начальника Української військово-медичної академії з наукової роботи, м. Київ, Україна.

Kix А. Ю., с ,D, E полковник медичної служби, канд. мед. наук, начальник Військово-медичного клінічного лікувально-реабілтаційного центру, м. Ірпінь.

Пархоменко Ю. О., С „D лейтенант медичної служби, слухач факультету підготовки військових лікарів Української військово-медичної академії, м.Київ.

Лук'янчук I. А., в, с, Е підполковник медичної служби, старший науковий співробітник науководослідного відділу спеціальної медицини та психофізіології НДІ проблем військової медицини, Українська військово-медична академія, м. Київ. 


\section{Сведения об авторах:}

Швец А. В., полковник медицинской службы, д-р мед. наук, старший научный сотрудник, заместитель начальника Украинской военно-медицинской академии по научной работе, г. Киев.

Ких А. Ю., полковник медицинской службы, канд. мед. наук, начальник Военно-медицинского клинического лечебно-реабилитационного центра, г. Ирпень.

Пархоменко Ю. О., лейтенант медицинской службы, слушатель факультета подготовки военных врачей Украинской военно-медицинской академии, г. Киев.

Лукьянчук И. А., одполковник медицинской службыстарший научный сотрудник научноисследовательского отдела специальной медицины и психофизиологии НИИ проблем военной медицины, Украинская военно-медицинская академия, г. Киев.

\section{Information about authors:}

Shvets A. V., Col. MS, MD, PhD, DSc, Senior Researcher, Deputy chief of Ukrainian Military Medical Academy for sciense, Kyiv. ORCID ID: 0000-0002-9461-7129.

Kikh A. Y., Col. MS, MD, PhD, Head of the Military Medical Clinical Treatment \& Rehabilitation Center, Irpin.

Parkhomenko Y. O., 2LT MS, student of the faculty of military doctors training of Ukrainian Military Medical Academy, Kyiv.

Lukianchuk I. A., LtC. MS, Senior Researcher of the Research Department of Special Medicine and Psychophysiology of Research Institute of Military Medicine, Ukrainian Military Medical Academy, Kyiv. 